\title{
sciendo
}

\section{THE UTILIZATION OF FULL-FAT INSECT MEAL IN RAINBOW TROUT (ONCORHYNCHUS MYKISS) NUTRITION: THE EFFECTS ON GROWTH PERFORMANCE, INTESTINAL MICROBIOTA AND GASTROINTESTINAL TRACT HISTOMORPHOLOGY*}

\author{
Agata Józefiak ${ }^{1}$, Silvia Nogales-Mérida², Zuzanna Mikołajczak²,3, Mateusz Rawski ${ }^{4}$, \\ Bartosz Kierończyk ${ }^{3}$, Jan Mazurkiewicz ${ }^{4}$
}

\author{
${ }^{1}$ Department of Preclinical Sciences and Infectious Diseases, Poznań University of Life Sciences, \\ Wołyńska 35, 60-637 Poznań, Poland \\ ${ }^{2}$ HiProMine S.A., 62-023 Robakowo, Poland \\ ${ }^{3}$ Department of Animal Nutrition, Poznań University of Life Sciences, Wołyńska 33, 60-637 Poznań, \\ Poland \\ ${ }^{4}$ Division of Inland Fisheries and Aquaculture, Institute of Zoology, Poznań University \\ of Life Sciences, Wojska Polskiego 71c, 60-625 Poznań, Poland \\ •Corresponding author: karp@up.poznan.pl
}

\begin{abstract}
A 71-day-long experiment was conducted to evaluate the inclusion of $20 \%$ Hermetia illucens (HI) meal; Tenebrio molitor (TM) meal; Gryllodes sigillatus (GS) meal; and Blatta lateralis (BL) meal in comparison to a control diet without any insect-based materials that used fish meal as the main source of protein. A total of 1950 rainbow trout juveniles $(53.39 \pm 3.74$ g) were used. The formulated diets were isonitrogenous $(45 \%)$ and isoenergetic $\left(10 \mathrm{MJ} \mathrm{kg} \mathrm{g}^{-1}\right)$. The inclusion of a full-fat insect meal did not affect the survival rate during the experimental period. The growth performance was significantly improved in the BL and TM treatments, while in the HI treatment was not affected. However, the GS treatment had a negative effect on the growth performance. The villus height decreased in the TM and GS treatment groups and increased in the BL diet group. The total number of bacteria increased in all insect meal diet groups. The results of the experiment show that $B$. lateralis, $\boldsymbol{T}$. molitor and $\boldsymbol{H}$. illucens full-fat meals can be used as a partial fish meal replacement without negative effects on survival or growth performance parameters. Moreover, full-fat insect meals may be considered as a protein source and a functional feed component that may positively affect the histomorphological structure of the fish gastrointestinal tract and stimulate the expansion of beneficial bacterial populations in the gut.
\end{abstract}

Key words: aquaculture, fish nutrition, gastrointestinal tract histomorphology, insect meals, microbiota, rainbow trout

*This work was supported by several sources: the funds of Poznań University of Life Sciences; TEAM TECH/2016-2/11-0026, project entitled: Insects as novel protein sources for fish and poultry, financed by the Foundation of Polish Science (POIR 4.4); as well as funds of the National Centre for Research and Development, no POIR.01.01.01-00-0828/15, entitled: InnSecta: innovative technology of feedstuffs production based on insect biomass. 
Aquaculture is the fastest growing branch of animal production; therefore, it must meet the requirements of sustainable development (Subasinghe et al., 2009). Moreover, in the 21 st century, fish farming will face two main challenges. The first is to feed an increasing human population that is estimated to reach 9.6-12.3 billion by the year 2100 (Gerland et al., 2014; Edgerton, 2009). The second, and probably more difficult, challenge is the transition from marine feed resources (fish meal and fish oil) to terrestrial substitutes (Lazzarotto et al., 2015). Several alternative meals based on plants and terrestrial animal by-products have been proposed and used. However, the uses of marine resource-free diets have been reported to have side effects, such as a reduction in growth performance and offspring survival (Lazzarotto et al., 2015) and diseases (Green et al., 2013) due to the presence of antinutritional factors (Francis et al., 2001). Moreover, most of the plant meals used in feeds are not part of a wild fish diet, which is not the case for insects. The prospect of the use of insects in fish diets seems to be promising because rainbow trout utilize insects in their natural diets (Aarnio et al., 1996; Andersen and Cheng, 2004; Ferriz et al., 2010; Orlov et al., 2006; Rikardsen and Sandring, 2006). Thus, the question should not be if insects should be incorporated into salmonid nutrition but, rather, which insects and in what form should insects be used. Therefore, in the current experiment, four insect species that are characterized by high nutritional values were evaluated as potentially sustainable alternatives for fish meal replacement. Considering the facts mentioned above, insects are one of the most promising sources of protein, which may help to cope with the increasing global demand for new protein sources for agriculture, thus representing the idea of "waste into feed" bioconversion (Józefiak D. et al., 2016; Józefiak A. et al., 2018; Kierończyk et al., 2018 a). Furthermore, the use of insect meals in aquaculture was approved in 2017 by the European Parliament and is under debate for other farm species. Several reviews and predictive studies show insect meal is a promising new direction for animal nutrition (Józefiak D. et al., 2016; Makkar et al., 2014; Nogales-Mérida et al., 2018; Sánchez-Muros et al., 2014; Mancuso et al., 2016). Insects are also considered to be a significant source of antimicrobial peptides (AMPs), and are possible feed attractants, which can be used to develop the natural bioactive compounds that are used in livestock production (Józefiak and Engberg, 2017; Kierończyk et al., 2018 b). Moreover, an overall increase in interest using insects as feed components has been observed, including in the nutrition of farm animals, aquaculture and ornamental fish (Belghit et al., 2018; Bruni et al., 2018; Elia et al., 2018; Józefiak D. et al., 2016; Józefiak A. et al., 2018; Kierończyk et al., 2018 a, b; Vargas et al., 2018; Vargas-Abundez et al., 2019; Zarantoniello et al., 2018). From both scientific and practical points of view, the status of the gastrointestinal tract (GIT) is one of the key determinants of how alternative meals affect animal health, as the GIT is the primary barrier for fish against the outside environment and has an effect on nutrient absorption (Halver and Hardy, 2002). Moreover, it is known that the type of feed will determine the microbiota composition that is present in the gut and its integrity (Egerton et al., 2018). However, the majority of previous studies have focused on the structure of fish microbiome, thus providing little knowledge about the effects of nutritional and environmental factors on the functional potential of the gut microbiome (Talwar et al., 2018). Therefore, more observations are needed 
in terms of the role of fish microbiomes in the host-microbiota interactions, and health benefit analysis should be used to evaluate the nutritional changes caused by microbiota modifications (Wang et al., 2018). Considering all of these facts, it was determined that the objective of this study was to evaluate and compare the effects of selected kinds of full-fat insect meals as a partial replacement for fish meal on the growth performance, intestinal microbiota and histomorphology of rainbow trout. The main goal was to answer questions about the effects of the high and fixed dose of insects in terms of fish growth performance, feed utilization, gastrointestinal tract microbiota, and histomorphology.

\section{Material and methods}

\section{Ethics statement}

The study was carried out in strict accordance with the recommendations of the National Ethics Commission (Warsaw, Poland). All members of the research staff were trained in animal care, handling and euthanasia by PolLASA (Polish Laboratory Animal Science Association). The welfare, health and environmental conditions in experimental tanks were checked twice daily by visual observations of animal behaviour, feed consumption and water quality parameters, such as oxygen saturation, temperature and water flow. All were measured continuously. All procedures and experiments complied with the guidelines of the Local Ethics Commission of the Poznań University of Life Sciences (Poznań, Poland) with respect to animal experimentation and the care of the animals in the study, and all efforts were made to minimize animal suffering. At the end of the experimental period, 10 animals per treatment were euthanized for the extraction of proximal intestine digesta and tissue sampling. Fish were anaesthetized with an overdose of tricaine methane sulfonate (MS222, $300 \mathrm{mg} \mathrm{l}^{-1}$ ) by prolonged immersion (Topic Popovic et al., 2012). When the animals were sedated, they were decapitated according to the AVMA Guidelines for the Euthanasia of Animals (Leary et al., 2013). These procedures were used to avoid contamination of the microbiota determination and quantification and to minimize fish suffering. According to Polish law and the EU directive (no 2010/63/EU), the experiment conducted within the study did not require approval from the Local Ethical Committee for Experiments on Animals in Poznań. The number of animals that were used in the experiment and the details of their euthanasia were reported to the Local Ethical Committee for Experiments on Animals in Poznan in a report for the year 2016 .

\section{Insect rearing and full-fat meal preparation}

Full-fat insect meals were produced by HiProMine S.A, (Robakowo, Poland). All insects were reared for experimental purposes, fed with a mixture of vegetable and wheat bran (50:50) based re-food diets. Black soldier fly (Hermetia illucens) prepupae were 14 days old, mealworm (Tenebrio molitor) larvae were 42 days old, and imagines for Indian house cricket (Gryllodes sigillatus) and Turkestan cockroach (Blatta lateralis) were 56 days old. The insect biomasses were frozen at $-20^{\circ} \mathrm{C}$ and 
air dried at $55^{\circ} \mathrm{C}$ for $24-48 \mathrm{~h}$, which is the time needed to reach a constant weight. Dried insects were finely ground with no additional conditioning. The chemical compositions of the obtained full-fat meals used in the experiment are presented in Table 1 and were analysed in an external, independent and certified laboratory (JSH Hamilton, Poland). For chemical analyses, representative samples of fish and insect meals were ground enough to pass through a $0.5-\mathrm{mm}$ sieve. The dry matter, crude protein, and crude fibre contents in the meal were determined according to AOAC (2007). The nitrogen content was analysed using a Kjeldahl Foss Automatic 16210 (A/S N. Foss Electric, Denmark) analyser. The fat content was determined using a Soxtec System HT 1043 Extraction Unit (Foss Tecator, Denmark). The amino acid content was determined using an AAA 400 automatic amino acid analyser and ninhydrin for post-column derivatization. Before the analyses, samples were hydrolysed with $6 \mathrm{~N}$ $\mathrm{HCl}$ for $24 \mathrm{~h}$ at $110^{\circ} \mathrm{C}(\mathrm{AOAC}, 2007)$.

Table 1. Chemical composition of fish meal and full-fat insect meals used in the experiment

\begin{tabular}{|c|c|c|c|c|c|}
\hline Items $\left(\mathrm{g} \mathrm{kg}^{-1}\right)$ & Fish meal $^{1}$ & $\begin{array}{c}\text { Hermetia } \\
\text { illucens }^{2}\end{array}$ & $\begin{array}{l}\text { Tenebrio } \\
\text { molitor }^{2}\end{array}$ & $\begin{array}{l}\text { Gryllodes } \\
\text { sigillatus }^{2}\end{array}$ & $\begin{array}{c}\text { Blatta } \\
\text { lateralis }^{2}\end{array}$ \\
\hline Dry matter & 900.0 & 975.0 & 939.0 & 946.0 & 949.0 \\
\hline Crude protein (DM) & 720 & 404.0 & 563.0 & 613.0 & 546.0 \\
\hline Crude fat (DM) & 120.0 & 335.0 & 253.0 & 195.0 & 261.0 \\
\hline Crude ash (DM) & 140.0 & 71.3 & 45.3 & 60.0 & 54.6 \\
\hline \multicolumn{6}{|c|}{ Amino acids quantification expressed in $\mathrm{g} \mathrm{kg}^{-1}$ of protein } \\
\hline \multicolumn{6}{|c|}{ Essential amino acids (EAA) } \\
\hline arginine & 37.2 & 19.3 & 24.1 & 35.2 & 30.7 \\
\hline histidine & 13.4 & 10.5 & 14.5 & 13.5 & 13.5 \\
\hline isoleucine & 30.2 & 16.3 & 23.0 & 22.7 & 17.1 \\
\hline leucine & 50.3 & 26.7 & 39.0 & 42.5 & 31.4 \\
\hline lysine & 50.3 & 22.5 & 27.5 & 32.4 & 26.6 \\
\hline methionine & 19.6 & 5.7 & 6.8 & 9.7 & 7.0 \\
\hline phenylalanine & 25.1 & 15.2 & 16.3 & 19.0 & 16.6 \\
\hline tyrosine & 19.5 & 24.1 & 25.3 & 25.7 & 30.5 \\
\hline valine & 36.3 & 22.6 & 33.1 & 31.6 & 28.0 \\
\hline \multicolumn{6}{|c|}{ Non essential amino acids (NEAA) } \\
\hline alanine & 42.8 & 25.8 & 48.0 & 47.0 & 38.0 \\
\hline aspartic acid & 61.1 & 30.5 & 36.6 & 47.9 & 37.0 \\
\hline glutamic acid & 91.8 & 46.4 & 60.0 & 64.2 & 56.1 \\
\hline glycine & 41.3 & 20.4 & 27.2 & 26.8 & 26.3 \\
\hline cysteine/cystine & 10.1 & 2.9 & 4.2 & 5.3 & 3.9 \\
\hline proline & 27.1 & 22.1 & 35.1 & 29.2 & 24.6 \\
\hline serine & 28.0 & 17.0 & 23.7 & 28.7 & 19.7 \\
\hline threonine & 27.7 & 14.7 & 20.5 & 21.7 & 17.8 \\
\hline EAA/NEAA & 8.7 & 9.1 & 8.2 & 8.6 & 9.0 \\
\hline
\end{tabular}

${ }^{1}$ Skagen, Denmark.

${ }^{2}$ Hipromine, Poland. 


\section{Animals and diets}

The growth trial was carried out using 1950 rainbow trout fingerlings (mean body weight $53.39 \pm 3.74 \mathrm{~g}$ ). The fingerlings were obtained from a commercial farm (Aquabiofarm, Trzcianka, Poland) and were randomly distributed into 15 rectangular fibreglass tanks $\left(600 \mathrm{dm}^{3}\right.$ capacity). A total of 390 fish were used per treatment with 130 fish per tank. The experiment was conducted over 71 days. The study design included five treatments with three replications per treatment, which is a standard number in aquaculture experiments (Florczyk et al., 2014; Mazurkiewicz et al., 2011). The experimental unit was arranged as an open-flow system. The water came directly from a river (Struga Dormowska) and was passed through a mechanical prefiltration chamber before it came into the tanks. For the duration of the experimental period, the temperature and dissolvent oxygen varied throughout the day, reflecting the natural conditions of the water source. The water flow rate allowed for the complete replacement of the total volume of water once per $h$. During the growth test, the average daily water temperature (Figure 1) ranged from 7.1 to $20.6^{\circ} \mathrm{C}$; the dissolved oxygen ranged from 4.3 to $11.2 \mathrm{mg} \mathrm{O}_{2} \mathrm{dm}^{-1}$ (WTW Multi Line P4 with optical oxygen sensor FDO 924, WTW, Weilheim, Germany); and the water $\mathrm{pH}$ ranged from 6.9 to 7.2 (WTW Multi Line P3 pH meter, WTW, Weilheim, Germany).

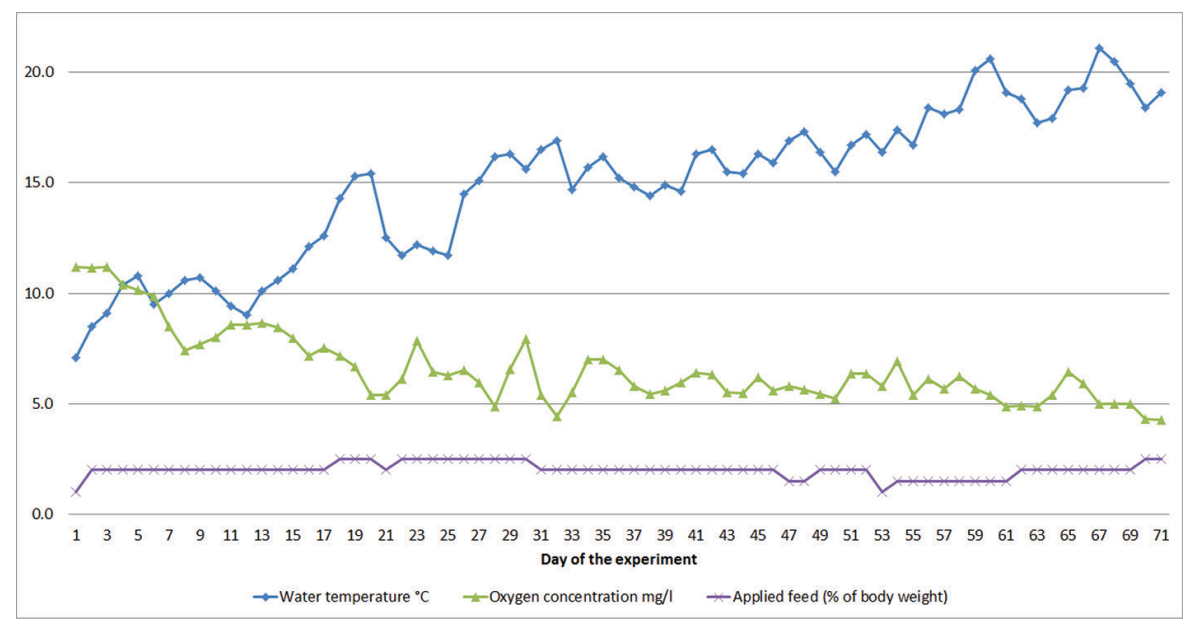

Figure 1. Relation between daily temperature, oxygen saturation and feed ratio along the experimental period

During the trial, the applied photoperiod was $16 \mathrm{~h}$ of light and $8 \mathrm{~h}$ of darkness. Artificial light $(6500 \mathrm{~K})$ was used. Waste from the tanks was removed daily using a water siphon. In this experiment, five isonitrogenous $(45 \%)$ and isoenergetic $\left(10 \mathrm{MJ} \mathrm{kg}^{-1}\right)$ diets were used. The control diet (CT) contained only fish meal as the main protein source. In the other four experimental treatments, $20 \%$ of the fish meal was replaced by full-fat insect meal from the prepupae of H. illucens, the larvae 
of T. molitor, and the imagines of G. sigillatus and B. lateralis. The experimental treatments were labelled "HI," "TM," "GS" and "BL," respectively. All diets were formulated according to rainbow trout amino acid requirements (Green and Hardy, 2002; Kurakawa et al., 2015; Ogino, 1980). Inclusion of 20\% insect meal was used according to previous preliminary data, and the optimal level that was suggested in previous scientific publications (Gasco et al., 2016; Kroeckel et al., 2012; Lock et al., 2015; Magalhães et al., 2017). The experimental diet formulations are given in Table 2. The chemical compositions and nutritional values of the diets as described above for animal meals are presented in Table 3. All experimental diets were processed by extrusion using a single-screw warm extruder (Metalchem S-60 Gliwice, Poland). The extrusion conditions were as follows: a $90^{\circ} \mathrm{C}$ cylinder temperature in the zone of increasing pressure, a $100^{\circ} \mathrm{C}$ cylinder temperature in the zone of high pressure, a $110^{\circ} \mathrm{C}$ head temperature, a $52 \mathrm{rpm}$ speed screw and a $6 \mathrm{~mm}$ nozzle diameter. Fish were fed for 15 hours every day using an automatic band feeder (08:00 h to 23:00 h). The daily diet ration ranged from 1 to $2.5 \%$ of fish body weight (based on water temperature and current fish weight), according to recommendations in the literature (Webster and Lim, 2002). The fish were weighed every ten days, after which the diet rations were adjusted.

Table 2. Formulation of the experimental diets for rainbow trout

\begin{tabular}{|c|c|c|c|c|c|}
\hline \multirow{2}{*}{ Ingredients $\left(\mathrm{g} \mathrm{kg}^{-1}\right)$} & \multicolumn{5}{|c|}{ Diets } \\
\hline & CT & HI & TM & GS & $\mathrm{BL}$ \\
\hline Fish meal $^{1}$ & 348.0 & 242.0 & 206.0 & 180.0 & 200.0 \\
\hline Turkestan cockroach (Blatta lateralis) $)^{2}$ & - & - & - & - & 200.0 \\
\hline Tropical house cricket (Gryllodes sigillatus) ${ }^{2}$ & - & - & - & 200.0 & - \\
\hline Mealworm (Tenebrio molitor $)^{2}$ & - & - & 200.0 & - & - \\
\hline Black soldier fly (Hermetia illucens) ${ }^{2}$ & - & 200.0 & - & - & - \\
\hline Red blood cells (dried) & 100 & 100 & 100 & 100 & 100.0 \\
\hline Yeasts & 40.0 & 40.0 & 40.0 & 40.0 & 40.0 \\
\hline Post-extraction soybean meal & 150.0 & 150.0 & 150.0 & 150.0 & 150.0 \\
\hline Wheat meal & 187.0 & 158.0 & 173.0 & 184.0 & 178.0 \\
\hline Fish oil & 157.0 & 92.0 & 113.0 & 128.0 & 114.0 \\
\hline Premix $^{3}$ & 15.0 & 15.0 & 15.0 & 15.0 & 15.0 \\
\hline Vitazol $\mathrm{AD}_{3} \mathrm{E}^{4}$ & 1.0 & 1.0 & 1.0 & 1.0 & 1.0 \\
\hline Choline chloride & 2.0 & 2.0 & 2.0 & 2.0 & 2.0 \\
\hline
\end{tabular}

CT: Control diet; HI: Hermetia illucens diet; TM: Tenebrio molitor diet; GS: Gryllodes sigillatus diet; BL: Blatta lateralis diet.

${ }^{1}$ Skagen, Denmark.

${ }^{2}$ HiProMine S.A. Robakowo, Poland.

${ }^{3}$ Premix W, BASF Polska Ltd. Kutno, Poland - containing per kg: vitamin A $1000000 \mathrm{IU}$, vitamin $\mathrm{D}_{3}$ $200000 \mathrm{IU}$, vitamin E $1.5 \mathrm{~g}$, vitamin K $0.2 \mathrm{~g}$, vitamin $\mathrm{B}_{1} 0.05 \mathrm{~g}$, vitamin $\mathrm{B}_{2} 0.4 \mathrm{~g}$, vitamin $\mathrm{B}_{12} 0.001 \mathrm{~g}$, nicotinic acid $2.5 \mathrm{~g}$, D-calcium pantothenate $1.0 \mathrm{~g}$, choline chloride $7.5 \mathrm{~g}$, folic acid $0.1 \mathrm{~g}$, methionine $150.0 \mathrm{~g}$, lysine 150.0 g, Fe 2.5 g, Mn 6.5 g, Cu 0.8 g, Co 0.04 g, Zn 4.0 g, I 0.008 g.

${ }^{4}$ Vitazol: Vitamin premix $\mathrm{AD}_{3} \mathrm{EC}$, BIOWET Drwalew, Poland - contains in $1 \mathrm{~kg}$ : vitamin A $50000 \mathrm{IU}$, vitamin $\mathrm{D}_{3} 5000 \mathrm{IU}$, vitamin E $30.0 \mathrm{mg}$, vitamin C $100.0 \mathrm{mg}$. 
Table 3. Calculated composition of the experimental diets

\begin{tabular}{|c|c|c|c|c|c|}
\hline \multirow{2}{*}{ Nutrients } & \multicolumn{5}{|c|}{ Diets } \\
\hline & $\mathrm{CT}$ & $\mathrm{HI}$ & $\mathrm{TM}$ & GS & BL \\
\hline Crude protein $\left(\mathrm{g} \mathrm{kg}^{-1} \mathrm{DM}\right)$ & 45.03 & 45.03 & 45.05 & 45.04 & 45.00 \\
\hline \multicolumn{6}{|c|}{ Essential amino acids ( $\mathrm{g} \mathrm{kg}^{-1}$ of protein) } \\
\hline arginine & 47.5 & 42.6 & 40.6 .4 & 44.5 & 43.6 \\
\hline histidine & 26.2 & 24.9 & 25.2 & 25.1 & 25.2 \\
\hline lysine & 38.9 & 36.6 & 36.6 & 37.8 & 36.5 \\
\hline tryptophan & 9.6 & 8.3 & 7.7 & 7.7 & 7.9 \\
\hline phenylalanine + tyrosine & 50.6 & 48.6 & 48.3 & 49.1 & 50.0 \\
\hline methionine + cystine & 14.2 & 12.7 & 12.8 & 13.7 & 12.8 \\
\hline threonine & 32.1 & 29.4 & 29.7 .0 & 29.9 & 29.2 \\
\hline leucine & 64.4 & 60.3 & 61.6 & 62.7 & 60.2 \\
\hline isoleucine & 39.2 & 36.2 & 36.7 & 36.4 & 35.5 \\
\hline valine & 47.6 & 45.2 & 46.7 .2 & 46.5 & 45.9 \\
\hline Crude fat ( $\left.\mathrm{g} \mathrm{kg}^{-1} \mathrm{DM}\right)$ & 200.2 & 200.8 & 200.6 & 200.5 & 200.7 \\
\hline $\mathrm{N}$-free extract $\left(\mathrm{g} \mathrm{kg}^{-1} \mathrm{DM}\right)$ & 206.4 & 188.2 & 188.6 & 190.8 & 188.3 \\
\hline Crude fibre ( $\left.\mathrm{g} \mathrm{kg}^{-1} \mathrm{DM}\right)$ & 18.9 & 17.3 & 17.9 & 18.4 & 18.0 \\
\hline Crude ash ( $\left.\mathrm{g} \mathrm{kg}^{-1} \mathrm{DM}\right)$ & 80.7 & 80.1 & 70.6 & 71.7 & 72.2 \\
\hline Calcium (g kg-1 DM) & 18.2 & 15.7 & 11.4 & 10.9 & 11.4 \\
\hline Phosphorus ( $\left.\mathrm{g} \mathrm{kg}^{-1} \mathrm{DM}\right)$ & 13.1 & 11.2 & 10.3 & 9.6 & 10.0 \\
\hline Gross energy $\left(\mathrm{MJ} / \mathrm{kg}^{-1}\right)$ & 10.13 & 10.04 & 10.03 & 10.04 & 10.04 \\
\hline
\end{tabular}

CT - control treatment $-34.8 \%$ of fish meal, $\mathrm{HI}-20 \%$ of Hermetia illucens full-fat meal and $24.2 \%$ of fish meal, TM $-20 \%$ of Tenebrio molitor full-fat meal and $20.6 \%$ of fish meal, GS $20 \%$ of Gryllodes sigillatus full-fat meal and $18.0 \%$ of fish meal, BL $-20 \%$ of Blatta lateralis full-fat meal and $20.2 \%$ of fish meal.

\section{Growth performance and diet utilization assessment}

The effects of the diets were evaluated on the basis of stock biomass and diet utilization equations, according to the literature (Halver and Hardy, 2002). At the end of the experiment, 10 animals per treatment were euthanized and dissected to obtain proximal intestine tissue samples and intestinal contents for further fluorescent in situ hybridization of single bacterial cells. Both analyses are described in detail below.

\section{Histological analyses}

Proximal intestine tissue samples were fixed immediately after dissection in a freshly prepared formaldehyde solution $\left(40 \mathrm{~g} \mathrm{~L}^{-1}\right.$ formaldehyde prepared in $0.01 \mathrm{M}$ PBS; $\mathrm{pH}=7.4$ ) and were incubated for $12 \mathrm{~h}$. Afterwards, the samples were dehydrated in a series of alcohol solutions, placed in xylene and then embedded in paraffin. At least 5 serial sections of $5 \mu \mathrm{m}$ were cut from each block and were stained with haematoxylin and eosin. The stained material was examined under an Axiophot OPTON light microscope with 40x magnification. The length of the villi was meas- 
ured from the top of the epithelium villi to its basis. In the cross-sections, the lengths of all villi with a complete structure were measured. Destroyed villi were excluded from the experiment. The villous height and the mucosa thickness were measured in 10 serial slides using a micrometer glass master $(0.01 \mathrm{~mm}, \mathrm{PZO}$, Warsaw, Poland) and were treated as the means. These values were used in further statistical analysis.

\section{Microbial community analysis by fluorescent in situ hybridization (FISH)}

The samples of the gastrointestinal content taken during fish dissection were immediately frozen and stored at $-80^{\circ} \mathrm{C}$. For the FISH analysis, $100 \mu \mathrm{L}$ digesta were diluted in PBS (0.13 M NaCl, $\left.10 \mathrm{mM} \mathrm{NaPO}_{4}, \mathrm{pH} 7.2\right)$ at a 1:9 ratio, sonicated (30 $\mathrm{kHz}$ for $20 \mathrm{sec}$ ), pipetted onto $0.22 \mu \mathrm{m}$ polycarbonate filters (Isopore ${ }^{\mathrm{TM}}$ Membrane Filters, GTBP02500) and vacuumed together with $10 \mathrm{~mL}$ PBS (Vacuum KNF Vacu Port-Neuberger). After vacuuming, the filters were transferred onto cellulose discs for dehydration in an ethanol series $(50,80$, and 90\%). They were then transferred onto discs rinsed with lysozyme, washed in PBS and dehydrated with the abovementioned ethanol solutions ( $3 \mathrm{~min}$ for each abovementioned stage). A series of identical filters was prepared for each sample to determine optimal hybridization (Manz et al., 1996; Rawski et al., 2016). The filters were air dried prior to hybridization. The oligonucleotide probes used for this study (Table 4) were selected from the literature and were used successfully in our previous studies on poultry and aquatic animals (Józefiak D. et al., 2011; Rawski et al., 2016, 2018). Hybridizations were carried out in $25 \mu \mathrm{L}$ wash buffer 1 with formamide $(0.9 \mathrm{M} \mathrm{NaCl} ; 20 \mathrm{mM}$ Tris/HCl, pH 7.2; $0.01 \%$ SDS ) containing $2 \mu \mathrm{L}$ oligonucleotide probes. After hybridization, the filters were immersed in deionized water and washed with a washing buffer ( $20 \mathrm{mM}$ Tris/ $\mathrm{HCl}, \mathrm{pH} 7.2 ; 0.01 \% \mathrm{SDS} ; 5 \mathrm{mM}$ EDTA) for $10 \mathrm{~min}$ at $50^{\circ} \mathrm{C}$. The filters were rinsed gently in distilled water, air-dried, and mounted on object glasses with VECTASHIELD (Vector laboratories no. H-1000) anti-fading agent containing DAPI (4',6-diamidino-2-phenylindole). To distinguish the total count (DAPI) of bacteria from other particles in the samples, oligonucleotide probes were labelled with DsRed and Alexa Fluor fluorochromes. The filters were left at $-80^{\circ} \mathrm{C}$ for $24 \mathrm{~h}$ in the dark until visualization using a Carl Zeiss Microscope Axio Imager M2. The numbers of detected bacteria are expressed in colony-forming units/g of digesta $\left(\mathrm{CFU} \mathrm{m} \mathrm{m}^{-1}\right)$ and were calculated according to the equation given below:

$$
\log C F U / g=\log \left[\left(N \times\left(\frac{W A}{P A}\right) \times\left(\frac{\text { Sweight }+ \text { Dweight }}{\text { Sweight }}\right) \times\left(\frac{1000}{\text { Svolume }}\right)\right]\right.
$$

where:

$N=$ number of visible bacterial cells,

$W A=$ the work area of the filter,

$P A=$ the picture area,

Sweight $=$ the sample weight,

Dweight $=$ the diluting factor weight,

Svolume $=$ the volume of the sample pipetted onto the filter. 
Table 4. Oligonucleotide probes used in fluorescent in situ hybridization

\begin{tabular}{|c|c|c|c|}
\hline Target & Probe & Sequence (5' to $\left.3^{\prime}\right)$ & References \\
\hline Enterobacteriaceae & Enter1432 & CTTTTGCAACCCACT & Sghir et al. (2000) \\
\hline Clostridium leptum subgroup & Clept1240 & GTTTTRTCAACGGCAGTC & Sghir et al. (2000) \\
\hline $\begin{array}{l}\text { Clostridium coccoides - } \\
\text { Eubacterium rectale cluster }\end{array}$ & Erec482 & GCTTCTTAGTCARGTACCG & Franks et al. (1998) \\
\hline Lactobacillus sp./Enterococcus sp. & Lab158 & GGTATTAGCAYCTGTTTCCA & Harmsen et al. (1999) \\
\hline
\end{tabular}

\section{Statistical analysis}

All data were tested for normal distribution using the Kruskal-Wallis test. Analysis of variance (ANOVA) was conducted using a Bartlett's test. When ANOVA showed the presence of significant differences, the post hoc Duncan's multiple range test at the significance level of $\mathrm{P}<0.05$ was used. The following general model was used:

$$
Y_{i}=\mu+\alpha_{i}+\delta_{i j}
$$

where:

$Y_{i}=$ the observed dependent variable,

$\mu=$ the overall mean,

$\alpha_{i}=$ the effect of the diet,

$\delta_{i j}=$ the random error.

\section{Results}

\section{Growth performance and diet utilization assessment}

The survival rates that were observed in the experiments were 97.3, 99.2, 98.2, 100, and 95.8 for the CT, HI, TM, GS, and BL treatments, respectively (Table 5). There were no statistically significant differences in mortality among treatments $(\mathrm{P}=0.0753)$. The growth performance results are also presented in Table 5 . The final (71st day) mean body weight of individual fish significantly increased $(\mathrm{p}=0.0371)$ in the BL treatment in comparison to the CT, HI, and GS groups. In the GS group, it was lower than that of the TM and BL diet groups. The specific growth rate was not affected among experimental periods and treatments; however, the total (1-71 days) value of the growth rate was negatively affected by the GS diet. The feed conversion ratio for the entire experimental period (1-71 days) increased $(\mathrm{P}=0.0178)$ only in the GS treatment, while no differences were recorded for all other treatments. The protein efficiency ratio did not differ $(\mathrm{P}=0.6637)$ between treatments. 
Table 5. Effect of selected insect meals on growth performance, nutrient retention and survival of rainbow trout

\begin{tabular}{|c|c|c|c|c|c|}
\hline Day & $\mathrm{CT}$ & $\mathrm{HI}$ & $\mathrm{TM}$ & GS & $\mathrm{BL}$ \\
\hline & \multicolumn{5}{|c|}{ Body weight gain (g) } \\
\hline 1 & $53.09 \pm 0.73$ & $53.30 \pm 0.73$ & $53.71 \pm 0.73$ & $53.71 \pm 0.73$ & $54.97 \pm 0.73$ \\
\hline 40 & $118.57 \pm 1.64$ & $118.44 \pm 1.64$ & $119.74 \pm 1.64$ & $116.64 \pm 1.64$ & $121.04 \pm 1.64$ \\
\hline \multirow[t]{2}{*}{71} & $165.92 \pm 6.28 \mathrm{bc}$ & $167.67 \pm 6.28 \mathrm{bc}$ & $171.49 \pm 6.28 \mathrm{ab}$ & $161.46 \pm 6.28 \mathrm{c}$ & $178.14 \pm 6.28 \mathrm{a}$ \\
\hline & \multicolumn{5}{|c|}{ Specific Growth Rate (SGR, \%/day) } \\
\hline $1-40$ & $2.10 \pm 0.06$ & $2.00 \pm 0.06$ & $2.00 \pm 0.06$ & $1.94 \pm 0.06$ & $1.97 \pm 0.06$ \\
\hline $41-71$ & $1.07 \pm 0.05$ & $1.17 \pm 0.05$ & $1.17 \pm 0.05$ & $1.07 \pm 0.05$ & $1.14 \pm 0.05$ \\
\hline \multirow[t]{2}{*}{$1-71$} & $1.67 \pm 0.04 \mathrm{a}$ & $1.62 \pm 0.04 \mathrm{a}$ & $1.63 \pm 0.04 \mathrm{a}$ & $1.56 \pm 0.04 b$ & $1.65 \pm 0.04 \mathrm{a}$ \\
\hline & \multicolumn{5}{|c|}{ Feed Conversion Rate (FCR) } \\
\hline $1-40$ & $0.94 \pm 0.02$ & $0.99 \pm 0.02$ & $0.99 \pm 0.02$ & $0.98 \pm 0.02$ & $0.99 \pm 0.02$ \\
\hline $41-71$ & $1.04 \pm 0.04$ & $0.95 \pm 0.04$ & $0.96 \pm 0.04$ & $1.02 \pm 0.04$ & $0.97 \pm 0.04$ \\
\hline \multirow[t]{2}{*}{$1-71$} & $0.95 \pm 0.02 \mathrm{~b}$ & $0.97 \pm 0.02 \mathrm{~b}$ & $0.96 \pm 0.02 \mathrm{~b}$ & $0.99 \pm 0.02 \mathrm{a}$ & $0.95 \pm 0.02 b$ \\
\hline & \multicolumn{5}{|c|}{ Protein Efficiency Ratio (PER) } \\
\hline $1-40$ & $2.37 \pm 0.05$ & $2.24 \pm 0.05$ & $2.26 \pm 0.05$ & $2.27 \pm 0.05$ & $2.24 \pm 0.05$ \\
\hline $41-71$ & $2.14 \pm 0.09$ & $2.34 \pm 0.09$ & $2.33 \pm 0.09$ & $2.18 \pm 0.09$ & $2.29 \pm 0.09$ \\
\hline $1-71$ & $2.27 \pm 0.01$ & $2.28 \pm 0.01$ & $2.26 \pm 0.01$ & $2.25 \pm 0.01$ & $2.27 \pm 0.01$ \\
\hline Survival 1-71 & $97.29 \pm 1.63$ & $99.22 \pm 1.63$ & $98.21 \pm 1.63$ & $100.0 \pm 1.63$ & $95.83 \pm 1.63$ \\
\hline
\end{tabular}

CT - control treatment $-34.8 \%$ of fish meal; $\mathrm{HI}-20 \%$ of Hermetia illucens full-fat meal and $24.2 \%$ of fish meal; TM $-20 \%$ of Tenebrio molitor full-fat meal and 20.6\% of fish meal; GS $20 \%$ of Gryllodes sigillatus full-fat meal and $18.0 \%$ of fish meal; BL $-20 \%$ of Blatta lateralis full-fat meal and $20.2 \%$ of fish meal. Different letters indicate significant differences between treatments $(\mathrm{P}<0.05)$.

Weight gain $(\mathrm{g})=[$ final weight $(\mathrm{g})$ - initial weight $(\mathrm{g})] /$ initial weight $(\mathrm{g})$.

\section{Histological analysis}

The histomorphological analysis results for the proximal intestine are presented in Table 6. The villus height decreased $(\mathrm{P}<0.0001)$ in the TM and GS treatment groups but increased in the BL diet group. The mucosa thickness decreased in the GS diet group, while it increased in the BL treatment group $(\mathrm{P}<0.0001)$.

Table 6. Histomorphology of the proximal intestine segment in rainbow trout fed with the selected insect meals

\begin{tabular}{l|c|c|c|c|c}
\hline & CT & HI & TM & GS & BL \\
\hline Villus height $(\mu \mathrm{m})$ & $457 \pm 37 \mathrm{~b}$ & $442 \pm 37 \mathrm{bc}$ & $422 \pm 37 \mathrm{c}$ & $410 \pm 36 \mathrm{c}$ & $504 \pm 38 \mathrm{a}$ \\
Mucosa thickness $(\mu \mathrm{m})$ & $527 \pm 39 \mathrm{~b}$ & $515 \pm 39 \mathrm{~b}$ & $494 \pm 38 \mathrm{~b}$ & $484 \pm 38 \mathrm{c}$ & $584 \pm 37 \mathrm{a}$ \\
\hline
\end{tabular}

CT - control treatment $-34.8 \%$ of fish meal; $\mathrm{HI}-20 \%$ of Hermetia illucens full-fat meal and $24.2 \%$ of fish meal; TM - $20 \%$ of Tenebrio molitor full-fat meal and $20.6 \%$ of fish meal; GS $-20 \%$ of Gryllodes sigillatus full-fat meal and $18.0 \%$ of fish meal; BL $-20 \%$ of Blatta lateralis full-fat meal and $20.2 \%$ of fish meal. Different letters indicate significant differences between treatments $(\mathrm{P}<0.05)$. 


\section{Microbial community analysis by fluorescence in situ hybridization (FISH)}

Results of the intestinal microbiota analysis are presented in Table 7 . The total number of bacteria increased $(\mathrm{P}<0.0001)$ in all experimental treatment groups compared with the CT group, with the highest value found in the TM treatment group. The value for the BL group was significantly lower than that for the TM treatment group but was higher than that found for the HI and GS diet groups. The concentration of Enterobacteriaceae increased $(\mathrm{P}=0.0042)$ in the TM treatment in comparison to that of the CT, the HI, and the GS treatment groups, but it did not differ from that of the BL diet. The Clostridium leptum subgroup counts increased $(\mathrm{P}<0.0001)$ in the TM, GS and BL treatment groups in comparison to that in the CT and HI treatments. Among the TM, GS and BL groups, the highest value was observed in the GS group and the lowest value was observed in the BL group, while the value of the TM group differed from the others. All experimental treatments (HI, TM, GS, and $\mathrm{BL}$ ) showed a significantly increased $(\mathrm{P}<0.0001)$ number of $C$. coccoides in comparison to the number found in trout receiving the CT diet. Among those with increased $C$. coccoides numbers, the highest values were observed in the TM and BL treatment groups, while bacterial concentrations in the GS and HI groups were significantly lower. Populations of Lactobacillus sp./Enterococcus sp. increased in the insect-containing diet groups. Among them, the highest value was observed in the TM treatment group.

Table 7. Intestinal microbiota of rainbow trout gastrointestinal tract

\begin{tabular}{l|c|c|c|c|c}
\hline \multicolumn{1}{c}{ Item } & CT & HI & TM & GS & BL \\
\hline \multicolumn{7}{c}{ Log CFU g $\mathbf{~ g}^{-1}$ of digesta } \\
Total number of bacteria & $9.51 \pm 0.11 \mathrm{~d}$ & $9.55 \pm 0.11 \mathrm{c}$ & $9.80 \pm 0.11 \mathrm{a}$ & $9.56 \pm 0.11 \mathrm{c}$ & $9.61 \pm 0.11 \mathrm{~b}$ \\
Enterobacteriaceae & $8.46 \pm 0.03 \mathrm{~b}$ & $8.45 \pm 0.03 \mathrm{~b}$ & $8.52 \pm 0.03 \mathrm{a}$ & $8.44 \pm 0.03 \mathrm{~b}$ & $8.50 \pm 0.03 \mathrm{ab}$ \\
Clostridium leptum subgroup & $8.30 \pm 0.18 \mathrm{~d}$ & $8.26 \pm 0.18 \mathrm{~d}$ & $8.53 \pm 0.18 \mathrm{~b}$ & $8.69 \pm 0.18 \mathrm{a}$ & $8.38 \pm 0.18 \mathrm{c}$ \\
Clostridium coccoides - & $8.13 \pm 0.14 \mathrm{~d}$ & $8.23 \pm 0.14 \mathrm{c}$ & $8.44 \pm 0.14 \mathrm{a}$ & $8.28 \pm 0.14 \mathrm{~b}$ & $8.47 \pm 0.14 \mathrm{a}$ \\
Eubacterium rectale cluster & & & & & \\
Lactobacillus sp. /Enterococcus sp. $8.10 \pm 0.27 \mathrm{c}$ & $8.69 \pm 0.27 \mathrm{~b}$ & $8.73 \pm 0.27 \mathrm{a}$ & $8.68 \pm 0.27 \mathrm{~b}$ & $8.67 \pm 0.27 \mathrm{~b}$ \\
\hline
\end{tabular}

CT - control treatment $-34.8 \%$ of fish meal; HI - 20\% of Hermetia illucens full-fat meal and $24.2 \%$ of fish meal; TM - $20 \%$ of Tenebrio molitor full-fat meal and $20.6 \%$ of fish meal; GS $-20 \%$ of Gryllodes sigillatus full-fat meal and $18.0 \%$ of fish meal; BL $-20 \%$ of Blatta lateralis full-fat meal and $20.2 \%$ of fish meal. Different letters indicate significant differences between treatments $(\mathrm{P}<0.05)$.

\section{Discussion}

The use of insect biomass in fish nutrition is one of the most interesting ideas for both science and practical aquafeed development (Morales-Ramos et al., 2014). In the current literature, an increasing interest in insect biomass usage is observed (Elia et al., 2018; Gasco et al., 2018; Kroeckel et al., 2012; Lock et al., 2015; Roncarati et al., 2015). To the authors' knowledge, the present study is the first of its kind to assess the partial replacement of fish meal with 4 variants of full-fat insect meal in rainbow trout nutrition. 


\section{Growth performance and diet utilization assessment}

Among all of the treatments, only the GS diet exhibited negative effects on the final mean body weight of fish from the use of insect meal, although it must be mentioned that fish that were fed the control diet also reduced their growth in comparison to fish that were fed the TM and BL diets. Moreover, a significant increase in body weight was recorded for fish that were given the BL treatment. Similarly, the HI, TM, and BL diets had no negative effects on the specific growth rate or feed conversion ratio, while the GS diet affected both growth and feed efficiency performance at the end of the experiment. Thus, the possibility of partially replacing fish meal in the diets of rainbow trout with full-fat TM, BL and HI meals was proven. The available publications show that the inclusion of insects in fish diets may have similar or slightly lower growth performance results (Barroso et al., 2014; Belghit et al., 2018; Vargas-Abundez et al., 2019). Due to a wide comparison of selected insect meals, probably for the first time, better growth performance results were shown in the case of feed containing 20\% BL meal in comparison to fish meal as the main animal protein source. According to published data, the black soldier fly and the mealworm seem to be the most studied species, probably due to their higher availability (Bondari and Sheppard, 1981; Gasco et al., 2016; Kroeckel et al., 2012; Ramos-Elorduy et al., 2002; Roncarati et al., 2015; Sánchez-Muros et al., 2015). Hermetia illucens was assessed as a valuable protein source in fish nutrition based on the growth performance results of catfish and tilapia (Bondari and Sheppard, 1981). In a study using turbot (Psetta maxima), the inclusion of H. illucens (33\% and more) had adverse effects on the growth performance results and decreased the apparent digestibility coefficients (Kroeckel et al., 2012). Similarly, the house fly maggot may be used successfully in the diet of Nile tilapia (Oreochromis niloticus), with dosing from $15 \%$ to $68 \%$ (Ogunji et al., 2007). Due to various effects from insect inclusion, a comparison is needed, as confirmed by the results of an experiment on Atlantic salmon (Salmo salar) post smolt. It was earlier shown that some variants of meal derived from the same species, black soldier fly meal may replace up to $100 \%$ of fish meal, while other variants of black soldier fly meal do not perform as well, probably due to differences in insect nutrition and material processing (Lock et al., 2015). Mealworm (T. molitor) was used as a substitute for fish meal in Nile tilapia and European sea bass (Dicentrarchus labrax) (Gasco et al., 2016; Sánchez-Muros et al., 2015). In Nile tilapia, the use of T. molitor meal and its mixture with soybean meal decreased fish body weight, but it improved the feed conversion ratio (Sánchez-Muros et al., 2015). In European sea bass, an inclusion level of $25 \%$ did not affect the growth performance results, while an inclusion level of 50\% worsened the growth performance (Gasco et al., 2016). In common catfish (Ameiurus melas) fingerlings, 50\% substitution of fish meal resulted in a decrease in the final body weight and the fish survival rate (Roncarati et al., 2015). In addition, a close relative of the mealworm, the superworm (Zophobas morio), seems to be a promising protein source and, according to an experiment on Nile tilapia, may be used to replace $25 \%$ of fish meal in the diet without adverse effects on growth performance (Jabir et al., $2012 \mathrm{a}, \mathrm{b}$ ).

The effects of insect meal inclusion in fish diets varied depending on the fish and insect species that were used in the experiment. Furthermore, according to the 
above discussed studies, insect feeding and processing seem to be important issues due to their effects on the chemical composition and nutritional quality of the meal. However, it may be concluded that, at the present level of knowledge, a 20-25\% share of insect meal may be included in fish diets, and further studies are needed to increase this proportion. The results of growth performance may also be explained by effects from the active antimicrobial fraction of insect protein, AMPs, which are considered to be growth promoters (Xiao et al., 2015). However, the negative effects on fish growth performance that are presented in the literature may be a consequence of high chitin levels in insect meals.

\section{Histomorphology and microbial communities in the gastrointestinal tract}

The villus height was increased in fish fed with the BL treatment. This increment can stimulate intestinal microstructure development, which promotes better feed utilization caused by an augmentation of the area of nutrient absorption. This may result in the increment of the intestinal permeability and enhanced efficiency of absorption and utilization of nutrients (Xiao et al., 2015). In contrast, a replacement of fishmeal by soybean meal in rainbow trout resulted in histomorphological alterations such as supranuclear vacuolization of the absorptive cells in the distal intestine epithelium, shortening of the heights of mucosal folds, and the presence of inflammatory cells (Heikkinen et al., 2006). Moreover, it was shown that in the case of zebrafish (Danio rerio) and clownfish (Amphiprion occelaris) no negative effects of insect-based (Hermetia illucens) diet were observed in terms of intestine and liver histomorphology (Vargas-Abundez et al., 2019; Zarantoniello et al., 2018). Most likely, for the first time, we have observed the stimulation of LAB bacteria (Lactobacillus sp./Enterococcus sp.) in rainbow trout due to the use of full-fat insect meal in their diets in comparison to fish meal. Together with the improved development of the GIT microstructure, the stimulation of LAB bacteria may be the mode of action for growth performance improvement in the BL treatment. Stimulation of lactic acid bacteria (LAB) may be interpreted as an effect of the prebiotic properties of chitosan and its oligosaccharide derivatives (chitooligosaccharides), which show antimicrobial, anti-inflammatory, anti-oxidative, antitumour, immunostimulatory and hypocholesterolaemic actions when fed as a dietary additive to farm animals (Świątkiewicz et al., 2014). It may also be suggested that LAB adhesion to the intestinal mucosa may improve the development of mucosa activity and the morphology of rainbow trout (Merrifield et al., 2010). The increased levels of LAB may have several beneficial effects on fish health due to immune system stimulation and a decrease in pathogens resulting from competitive exclusion (Fuller, 1989). Lactic acid bacteria, populations of which were increased by a full-fat insect meal, are considered to be probiotic populations in fish. In indigenous microbiota, they may be the first line of defence against pathogens, thereby stimulating immune system response and nutrient digestibility (Nayak, 2010 a, b). Conversely, an earlier study showed that soybean meal use in the rainbow trout diet decreased levels of LAB after 8 weeks of feeding (Heikkinen et al., 2006). The majority of intestinal microbiota in fish are considered to be resistant to nutritional and environmental factors. However, in a study performed on cultured rainbow trout, it was observed that the source of protein in their diet 
may affect both LAB as well as the density and richness of Clostridia (Wong et al., 2013). It was previously documented that the use of insect meals (Hermetia illucens origin) in rainbow trout may increase the microbiome biodiversity in both mucosa- and digesta-associated bacteria (Bruni et al., 2018). The increasing growth of $C$. coccoides in our work should be evaluated as a positive result that effects gut microbiome homeostasis. These bacteria play an important role in the maintenance of overall gut function. C. coccoides are commensal gut microbiota and constitute the anatomical barrier, along with the mucous layer and the intestinal epithelial monolayer. C. coccoides consist of one of the most abundant bacterial populations of commensal microbiota and are considered to be a group of bacteria that play important roles in immunology, nutrition, and pathological processes; hence, they play an important role in the health of their hosts (Liu et al., 2016). A metagenomic analysis of bacterial genome faeces samples of wild freshwater fish has shown that the most abundant bacteria of fish gut microbiome are Clostridia. They interact with other resident microbe populations but also provide specific and essential functions (Frank et al., 2007; Liu et al., 2016; Ye et al., 2014). The results of our study indicate a simultaneous increase in the population of $C$. coccoides in the BL treatment group and confirm that the presence of Clostridia in fish may have a balancing effect on gut homeostasis (Kurakawa et al., 2015). It may also be assumed that Clostridia could play an important role in host-microbiota competition or contain a potentially pathogenic species for fish. Another possible mode of microbiota improvement by full-fat insect meal may be the antimicrobial activity of AMPs (Józefiak and Engberg, 2017). The modulating effect of insect AMPs on the intestinal microbiome has been reported in many studies on farm animals (Wu et al., 2012; Xiao et al., 2015; Yoon et al., 2012, 2013, 2014).

The results of our study confirm the results of studies performed by other researchers in that both sets of the results show that insect protein can have beneficial effects on the growth performance, the survival rate, nutrient digestibility, the intestinal histomorphology and the microbiomic homeostasis of fish (Tang Z. et al., 2009; Tang X. et al., 2012; Wu et al., 2012; Yoon et al., 2012, 2014). These results show a large potential for substituting fish meal with full-fat insect meal, especially BL and TM meals, which positively affects the growth performance and feed efficiency of rainbow trout. Thus, further research should be conducted to optimize the diet formulation and the form and level of insect full-fat meal inclusion in aquaculture nutrition. This study also showed the positive effects of some insect meals, such as BL, HI and TM meals, in enhancing the gastrointestinal morphology and the colonization of beneficial bacteria, such as Lactobacillus sp., which are well-known for their probiotic effects in animal nutrition. These side effects on the fish gastrointestinal tract could help fish reach a similar final growth to that of fish fed with fishmeal, which is the most important protein source in carnivorous fish. Finally, in studies on some insect meals used in fish nutrition, the economic impact on profitability should be assessed. Considering the decreasing prices of insect protein production and the increasing prices of fish meal, the equal or even slightly lower growth performance of fish may become more profitable than continuing to use fish meal. 


\section{Acknowledgements}

This work was supported by several sources: the funds of Poznań University of Life Sciences; TEAM TECH/2016-2/11-0026, project entitled: Insects as novel protein sources for fish and poultry, financed by the Foundation of Polish Science (POIR 4.4); as well as funds of the National Centre for Research and Development, no POIR.01.01.01-00-0828/15, entitled: InnSecta: innovative technology of feedstuffs production based on insect biomass.

\section{References}

A a r n i o K., B o n s d or ff E., R o s e n b a c k N. (1996). Food and feeding habits of juvenile flounder Platichthys flesus (L.), and turbot Scophthalmus maximus L. in the Åland Archipelago, Northern Baltic Sea. J. Sea Res., 36: 311-320.

A n d ers en N.M., Cheng L. (2004). The marine insect Halobates (Heteroptera: Gerridae): Biology, adaptations, distribution, and phylogeny. Oceangr. Mar. Biol., 42: 119-180.

Association of Official Analytical Chemists (AOAC) (2007). Official Methods of Analysis, 18th edition. AOAC, Arlington, Virginia, USA.

Barroso F.G., de Haro C., Sánchez-Muros M.J., Venegas E., Martínez-Sánc he z A., Pérez-B a ñón C. (2014). The potential of various insect species for use as food for fish. Aquaculture, 422: 193-201.

B elghit I., Liland N.S., Waagbø R., Biancarosa I., Pelusio N., Li Y., Lock E.J. (2018). Potential of insect-based diets for Atlantic salmon (Salmo salar). Aquaculture, 491: 72-81.

B ond ari K., She p pard D.C. (1981). Soldier fly larvae as feed in commercial fish production. Aquaculture, 24: 103-109.

B run i L., Pastorelli R., Vit i C., Ga s c o L., P a r is i G. (2018). Characterisation of the intestinal microbial communities of rainbow trout (Oncorhynchus mykiss) fed with Hermetia illucens (black soldier fly) partially defatted larva meal as partial dietary protein source. Aquaculture, 487: 56-63.

E d g e rt o n M.D. (2009). Increasing crop productivity to meet global needs for feed, food, and fuel. Plant Physiol., 149: 7-13.

Egerton S., Culloty S., Who ol e y J., S tanton C., R os s R.P. (2018). The gut microbiota of marine fish. Front. Microbiol., 9: 1-17.

Elia A.C., C a puc ch i o M.T., C a la droni B., Magara G., Jozef A., Dörr M., B i a s a to E., Righeltt i M., Pastorino P., P arearo M., Frances co G., S chiavone A., Gas co L. (2018). Influence of Hermetia illucens meal dietary inclusion on the histological traits, gut mucin composition and the oxidative stress biomarkers in rainbow trout (Oncorhynchus mykiss). Aquaculture, 496: 50-57.

F erriz R.A., B a i gú n C.R.M., D o min in o J. (2010). Distribution patterns and trophic characteristics of salmonids and native species inhabiting high altitude rivers of Pampa de Achala region, Argentina. Neotrop. Ichthyol., 8: 851-860.

Florczyk K., M a zurki ew i c z J., Przybylska K., Ulikowski D., Szczepkowski M., Andrzejewski W., Golski J. (2014). Growth performance, feed intake and morphology of juvenile European catfish, Silurus glanis (L.) fed diets containing different protein and lipid levels. Aquac. Int., 22: 205-214.

Francis G., Makkar H.P., B e cker K. (2001). Antinutritional factors present in plant-derived alternate fish feed ingredients and their effects in fish. Aquaculture, 199: 197-227.

Frank D.N., A mand A.L.S., F eldman R.A., B o edeker E.C., Harpaz N., P a ce N.R. (2007). Molecular-phylogenetic characterization of microbial community imbalances in human inflammatory bowel diseases. Proc. Nat. Acad. Sci., 104: 13780-13785.

Franks A.H., Harms e n H.J., R a ang s G.C., J a n s e n G.J., S c h u t F., We 11 ing G.W. (1998). 
Variations of bacterial populations in human feces measured by fluorescent in situ hybridization with group-specific 16S rRNA-targeted oligonucleotide probes. Appl. Env. Microbiol., 64: 3336-3345.

F u 11 e r R. (1989). Probiotics in man and animals. J. Appl. Bact., 66: 365-378.

Gas co L., Henry M., P i c colo G., Marono S., Gai F., Renna M., Luis si ana C., Antonop oulou, E., M o la P., Chat z ifot is S. (2016). Tenebrio molitor meal in diets for European sea bass (Dicentrarchus labrax L.) juveniles: Growth performance, whole body composition and in vivo apparent digestibility. Anim. Feed Sci. Tech., 220: 34-45.

Gas co L., Finke M., Hu is van A. (2018). Can diets containing insects promote animal health? J. Ins. Food Feed., 4: 1-4.

G e r l and P., R a ft e ry A.E., Š e včík ová H., Li N., Gu D., S poor en berg T., A 1 k e ma L., Fosdick B., Chunn J., Laic N., Bay G., Buettner T., Heilig G., Wilmoth J. (2014). World population stabilization unlikely this century. Science, 346: 234-237.

Green J.A., Hardy R.W. (2002). The optimum dietary essential amino acid pattern for rainbow trout (Oncorhynchus mykiss), to maximize nitrogen retention and minimize nitrogen excretion. Fish Physiol. Bioch., 27: 97-108.

Green T.J., S mullen R., B arnes A.C. (2013). Dietary soybean protein concentrate-induced intestinal disorder in marine farmed Atlantic salmon, Salmo salar is associated with alterations in gut microbiota. Vet. Microbiol., 166: 286-292.

H a lve r J.E., H a r d y R.W. (2002). (Eds). Fish Nutrition. San Diego, USA, Academic Press, 3rd ed., $824 \mathrm{pp}$.

Harmsen H.J., Elfferich P., Schut F., Welling G.W. (1999). A 16S rRNA-targeted probe for detection of lactobacilli and enterococci in faecal samples by fluorescent in situ hybridization. Microb. Ecol. Health Dis., 11: 3-12.

Heikkinen J., Vielma J., Kemiläinen O., Tiirola M., Eskelinen P., Kiuru T., Navia-Paldanius D., von Wright A. (2006). Effects of soybean meal based diet on growth performance, gut histopathology and intestinal microbiota of juvenile rainbow trout (Oncorhynchus mykiss). Aquaculture, 261: 259-268.

J a b i r M., J a b ir S.A.R., Vikin e s w a ry S. (2012 a). Nutritive potential and utilization of super worm (Zophobas morio) meal in the diet of Nile tilapia (Oreochromis niloticus) juvenile. Afr. J. Biotechnol., 11: 6592-6598.

J a b i r M., R a z a k S., Vi k in e s w a r y S. (2012 b). Chemical composition and nutrient digestibility of super worm meal in red tilapia juvenile. Pak. Vet. J., 32: 489-493.

J ó z e fi a k A., En g b e r g R.M. (2017). Insect proteins as a potential source of antimicrobial peptides in livestock production, J. Anim. Feed Sci., 26: 87-99.

Józefiak A., Ki erończyk B., Raw ski M., Mazurkiewicz J., B enzertiha A., Gobbi P., Nogales-Mérida S., Świątkiewicz S., Józefiak D. (2018). Full-fat insect meals as feed additive - the effect on broiler chicken growth performance and gastrointestinal tract microbiota. J. Anim. Feed Sci. 27: 131-139.

Józefiak D., S i p A., Rawski M., Rutkowski A., Kaczmarek S., Hojberg O., Jen s e n B.B., E n g b e r g R.M. (2011). Dietary divercin modifies gastrointestinal microbiota and improves growth performance in broiler chickens. Br. Poult. Sci., 52: 492-499.

Jó ze fi a k D., Jó z e fi a k A., K i e rońc zy k B., R a w s ki M. Ś w i ą t k i e w i c z S., Dług o s z J., Engberg R.M. (2016). Insects - a natural nutrient source for poultry - a review. Ann. Anim. Sci., 16: $297-313$.

Ki erończyk B., Rawski M., Józe fiak A., Mazurkiewicz J., Świątkiewicz S., Siwek M., B ednarczyk M., Szumacher-Strabel M., Cieślak A., Benzertiha A., J ó z e fi a k D. (2018 a). Effects of replacing soybean oil with selected insect fats on broilers. Anim. Feed Sci. Tech., 240: 170-183.

Kierończyk B., Rawski M., Pawełczyk P., Różyńska J., Golusik J., Mikołajc z a k Z., Jó z e fi a k D. (2018 b). Do insects smell attractive to dogs? A comparison of dog reactions to insects and commercial feed aromas - a preliminary study. Ann. Anim. Sci., 18: 795-800.

Kroeckel S., Harjes A-G., Roth I., Katz H., Wuertz S., Susenbeth A., Schulz C. (2012). When a turbot catches a fly: Evaluation of a pre-pupae meal of the Black Soldier Fly (Hermetia illucens) as fish meal substitute - Growth performance and chitin degradation in juvenile turbot (Psetta maxima). Aquaculture, 364: 345-352. 
Kurakawa T., Ogat a K., Matsuda K., Tsuji H., Kubota H., Takada T., Ka do Y., A sa hara T., Takahashi T., Nomoto K. (2015). Diversity of intestinal Clostridium coccoides group in the Japanese population, as demonstrated by reverse transcription-quantitative PCR. PloS One, 10: 1-19.

Lazzarot to V., Corraze G., Le prevost A., Quillet E., Dupont-Nivet M., Médale F. (2015). Three-year breeding cycle of rainbow trout (Oncorhynchus mykiss) fed a plant-based diet, totally free of marine resources: consequences for reproduction, fatty acid composition and progeny survival. PloS One, 10: 1-17.

Le ary S., Underwood W., Anthony R., Cartner S., Corey D., Grandin T., Greenacre C., Gwaltney-Brant S., McCrackin M.A., Meyer R., Miller D., She arer J., Yan ong R. (2013). AVMA Guidelines for the euthanasia of animals. Illinois, USA: American Veterinary Medical Association, pp. 67-72.

Liu H., Guo X., Gooneratne R., Lai R., Zeng C., Zhan F., Wang W. (2016). The gut microbiome and degradation enzyme activity of wild freshwater fishes influenced by their trophic levels. Sci. Rep., 6: 1-12.

L o ck E., A r s iw a 11 a T., Wa g bø R. (2015). Insect larvae meal as an alternative source of nutrients in the diet of Atlantic salmon (Salmo salar) postsmolt. Aquac. Nutr., 22: 1202-1213.

Magalhães R., Sánchez - López A., Silva Leal R., Martínez-Llorens S., Oliva - Te le s A., P e re s H. (2017). Black soldier fly (Hermetia illucens) pre-pupae meal as a fish meal replacement in diets for European seabass (Dicentrarchus labrax). Aquaculture, 476: 79-85.

Makkar H.P.S., Tran G., He u z é V., A n kers P. (2014). State-of-the-art on use of insects as animal feed. Anim. Feed Sci. Tech., 197: 1-33.

M a n c u s o T., B a ld i L., G a s c o L. (2016). An empirical study on consumer acceptance of farmed fish fed on insect meals: the Italian case. Aquacult. Int., 24: 1489-1507.

Manz W., A mann R., Ludwig W., Vancanneyt M., S chleifer K-H. (1996). Application of a suite of $16 \mathrm{~S}$ rRNA-specific oligonucleotide probes designed to investigate bacteria of the phylum Cytophaga-Flavobacter-Bacteroides in the natural environment. Microbiology, 142: 1097-106.

M a z u rki e w i c z J., Pr z y b ył A., Czyżak-Runowska G., Łyczyński A. (2011). Cold-pressed rapeseed cake as a component of the diet of common carp (Cyprinus carpio L.): effects on growth, nutrient utilization, body composition and meat quality. Aquac. Nutr. 17: 387-394.

Merrifi e ld D.L., H a r p e r G.M., D i m itroglou A., R ing ø E., D a vi e s S.J. (2010). Possible influence of probiotic adhesion to intestinal mucosa on the activity and morphology of rainbow trout (Oncorhynchus mykiss) enterocytes. Aquacult. Res., 41: 1268-1272.

Morales-R a mos M.G, R oj as G., S h a p iro-Il an D. (2014). (Eds). Mass production of beneficial organisms. Cambridge, USA, Academic Press - Elservier, 565-582 pp.

N a y a k S.K. (2010 a). Probiotics and immunity: a fish perspective. Fish Shellfish Immunol., 29: 2-14.

$\mathrm{N}$ a y a k S.K. (2010 b). Role of gastrointestinal microbiota in fish. Aquacult. Res., 41: 1553-1573.

Nogales-Mérida S., Gobbi P., Józefiak D., Mazurkiewicz J., Dudek K., Raws ki M., K i e rończy k B., Józe fi a k A. (2018). Insect meals in fish nutrition. Rev. Aquacult., 10: $1-24$.

O g i n o C. (1980). Requirements of carp and rainbow trout for essential amino acids. Bulletin of the Japanese Society for the Science of Fish, 46: 171-174.

Ogunji J.O., Nimptsch J., Wiegand C., Schulz C. (2007). Evaluation of the influence of housefly maggot meal (magmeal) diets on catalase, glutathione S-transferase and glycogen concentration in the liver of Oreochromis niloticus fingerling. Comp. Biochem. A Mol. Integr Physiol., 147: 942-947.

Orlov A.V., G e r a s i m o v Y.V., L a p s h in O.M. (2006). The feeding behavior of cultured and wild Atlantic salmon Salmo salar L., in the Louvenga river, Kola peninsula, Russia. ICES J. Mar. Sci., 63: $1297-1303$.

Ramos-Elorduy J., González E.A., Hernández A.R., Pino J.M. (2002). Use of Tenebrio molitor (Coleoptera: Tenebrionidae) to recycle organic wastes and as feed for broiler chickens. J. Econ. Entomol., 95: 214-220.

Rawski M., Ki erończyk B., Długosz J., Świątkiewicz S., Józefiak D. (2016). Dietary probiotics affect gastrointestinal microbiota, histological structure and shell mineralization in turtles. PLoS One, 11: 1-12. 
R aw s k i M., Ki e roń c z y k B., Św i ą t k i e w i c z S., Jó ze fi a k D. (2018). Long-term study on single and multiple species probiotic preparations for Florida softshell turtle (Apalone ferox) nutrition. Anim. Sci. Pap. Rep., 36: 87-98.

R i k a rd s e n A.H., S a n d r ing S. (2006). Diet and size-selective feeding by escaped hatchery rainbow trout Oncorhynchus mykiss (Walbaum). ICES J. Mar. Sci., 63: 460-465.

R o n c arati A., G a s c o L., Paris i G., Terova G. (2015). Growth performance of common catfish (Ameiurus melas Raf.) fingerlings fed mealworm (Tenebrio molitor) diet. J. Ins. Food Feed, 1: 233-240.

Sánchez-Muros M.J., Barroso F.G., Manzano-Agugliaro F. (2014). Insect meal as renewable source of food for animal feeding: a review. J. Clean. Prod., 65: 16-27.

Sánchez-Muros M.J., Haro C., S anz A., Trenzado C., Villareces S., Barroso F. (2015). Nutritional evaluation of Tenebrio molitor meal as fishmeal substitute for tilapia (Oreochromis niloticus) diet. Aquac. Nutr., 22: 943-955.

Sghir A., Gramet G., Suau A., R ochet V., P o chart P., Dore J. (2000). Quantification of bacterial groups within human fecal flora by oligonucleotide probe hybridization. Appl. Env. Microbiol., 66: 2263-2266.

Subas inghe R., S ot o D., Jia J. (2009). Global aquaculture and its role in sustainable development. Rev. Aquacult., 1: 2-9.

Świątkiewicz S., Św iątkiewicz M., A rczewska-Włosek A., Józefiak D. (2014). Chitosan and its oligosaccharide derivatives (chito-oligosaccharides) as feed supplements in poultry and swine nutrition. J. Anim. Physiol. Anim. Nutr., 99: 1-15.

Ta lw ar C., N a gar S., L a 1 R., N e gi R.K. (2018). Fish gut microbiome: current approaches and future perspectives. Indian J. Microbiol., 58: 397-414.

Tang X., F a tu fe A.A., Y in Y., Tang Z., Wang S., Li u Z., L i X., L i T. (2012). Dietary supplementation with recombinant lactoferrampin-lactoferricin improves growth performance and affects serum parameters in piglets. J. Anim. Vet. Adv., 11: 2548-2555.

Tang Z., Y in Y., Zhang Y., Huang R., S un Z., Li T., Chu W., Kong X., Li L., Geng M., $\mathrm{Tu}$ Q. (2009). Effects of dietary supplementation with an expressed fusion peptide bovine lactoferricin-lactoferrampin on performance, immune function and intestinal mucosal morphology in piglets weaned at age $21 \mathrm{~d}$. Brit. J. Nutr., 101: 998-1005.

Topic Popovic N., Strunjak-Perovic I., Coz-Rakovac R., Barisic J., Jadan M., Persin Berakovic A., Sauerborn Klobucar R. (2012). Tricaine methane-sulfonate (MS-222) application in fish anaesthesia. J. Appl. Ichthyol., 28: 553-564.

Vargas A., Randazzo B., Riolo P., Truzzi C., Gioacchini G., Giorgini E., Loreto N., Ruschioni S., Zarantoniello M., Antonucci M., Polverini S., Cardinaletti G., S abbatni S., Tulli F., Olivotto I. (2018). Rearing zebrafish on black soldier fly (Hermetia illucens): biometric, histological, spectroscopic, biochemical, and molecular implications. Zebrafish, 15: 404-419.

Vargas-Abundez J.A., Randazzo B., Foddai M., Sanchini L., Truzzi C., Giorg in i E., G a s c o L., O li v o t t o I. (2019). Insect meal based diets for clownfish: biometric, histological, spectroscopic, biochemical and molecular implications. Aquaculture, 498: 1-11.

Wang A.R., Ran C., Ringø E., Zhou Z.G. (2018). Progress in fish gastrointestinal microbiota research. Rev. Aquacult., 10: 626-640.

W e b s te r C.D., L i m C. (2002). (Eds). Nutrient requirements and feeding of finfish for aquaculture. Oxon, United Kingdom, CABI Publishing, pp. 184-201.

Wong S., Waldrop T., Summerfelt S., Davidson J., Barrows F., Kenney P.B., We lch T., We in s G.D., S n e kvik K., R aw ls J.F., G o od C. (2013). Aquacultured rainbow trout (Oncorhynchus mykiss) possess a large core intestinal microbiota that is resistant to variation in diet and rearing density. Appl. Environ. Microbiol., 79: 4974-4984.

Wu S., Zhang F., Huang Z., Liu H., Xi e C., Zhang J., Thacker P.A., Qi a o S. (2012). Effects of the antimicrobial peptide cecropin AD on performance and intestinal health in weaned piglets challenged with Escherichia coli. Peptides, 35: 225-230.

Xi a o H., Shao F., Wu M., Ren W., Xiong X., Tan B., Ying Y. (2015). The application of antimicrobial peptides as growth and health promoters for swine. J. Anim. Sci. Biot., 6: 1-6.

Ye L., A m berg J., Ch a p m a n D., G a i k o w s k i M., L i u W.T. (2014). Fish gut microbiota analy- 
sis differentiates physiology and behavior of invasive Asian carp and indigenous American fish. Mult. J. Microbial Ecol. (ISME), 8: 541-551.

Yoon J., Ingale S., Kim J., Kim K., Lee S., Park Y., Lee S.C., Kwon I.K., Chae B.J. (2012). Effects of dietary supplementation of antimicrobial peptide-A3 on growth performance, nutrient digestibility, intestinal and fecal microflora and intestinal morphology in weanling pigs. Anim. Feed Sci. Tech., 177: 98-107.

Yoon J., Ingale S., Kim J., Kim K., Lee S., Park Y., Lee S.C., Kwon I.K., Chae B.J. (2014). Effects of dietary supplementation of synthetic antimicrobial peptide-A3 and P5 on growth performance, apparent total tract digestibility of nutrients, fecal and intestinal microflora and intestinal morphology in weanling pigs. Liv. Sci., 159: 53-60.

Yoon J.H., Ingale S.L., Kim J.S., Kim K.H., Lohakare J., Park Y.C., Kwon I.K., Cha e B.J. (2013). Effects of dietary supplementation with antimicrobial peptide-P5 on growth performance, apparent total tract digestibility, faecal and intestinal microflora and intestinal morphology of weanling pigs. J. Sci. Food Agri., 93: 587-592.

Zarantoniello M., Bruni L., Randazzo B., Vargas A., Giocachini G., Truzzi C., Annibaldi A., Riolo P., Parisi G., Cardinaletti G., Trulli F., Olivoto I. (2018). Partial dietary inclusion of Hermetia illucens (black soldier fly) full fat prepupae in zebrafish feed: biometric, histological, biochemical and molecular implications. Zebrafish, 5: 519-532.

Received: 14 VIII 2018

Accepted: 1 III 2019 